J. Clin. Chem. Clin. Biochem.

Vol. 28, 1990, pp. $459-463$

(C) 1990 Walter de Gruyter \& Co. Berlin · New York

\title{
Aluminium Binding to Serum Constituents: A Role for Transferrin and for Citrate
}

\author{
By M. F. van Ginkel ${ }^{1}$, G. B. van der Voet ${ }^{1}, H$. G. van Eijk ${ }^{2}$ and F. A. de Wolff ${ }^{1}$ \\ 1 Laboratorium voor Toxicologie, Academisch Ziekenhuis Leiden, Leiden, Nederland \\ ${ }^{2}$ Chemische Pathologie, Erasmus Universiteit, Rotterdam, Nederland
}

(Received October 23, 1989/April 12, 1990)

Summary: The binding of aluminium in rat serum was studied. Rats were loaded intraperitoneally with different doses of aluminium(III)chloride 4 times during one week, before being killed by cardiac puncture.

One $\mathrm{ml}$ of serum was applied to a Sephacryl S-200 SF column and 70 fractions were collected. In the collected fractions, the distribution of aluminium was measured and compared with the concentrations of total protein, transferrin, and citrate.

The presence of a high molecular weight aluminium-complex in serum is confirmed. Although a possible role for albumin cannot be excluded, it is most likely that transferrin plays a role as a carrier for biological transport of aluminium in plasma. In addition to transferrin, aluminium was shown to be associated with citrate in serum, resulting in a low-molecular weight complex. It is postulated that citrate acts as a chelator for aluminium, and that the $\mathrm{Al} /$ citrate complex in serum may play an important role in intracellular accumulation, and hence the toxicity, of aluminium.

\section{Introduction}

It is generally accepted that aluminium is the cause of the dialysis-related diseases, microcytic anaemia, vitamin D-resistant osteomalacia, and dialysis encephalopathy $(1-3)$. Controversial, however, is the role of aluminium in the pathogenesis of some neurological disorders such as Alzheimer's disease, amyotrophic lateral sclerosis, and Parkinsonian dementia $(4-7)$.

Mammalian toxicity of aluminium is dependent on the bioavailability as well as on the chemical form of the element. Although the chemical speciation of aluminium in serum may be essential for understanding the (neuro-)toxic effects of this metal, little interest has been given to this aspect. Speciation studies using gel filtration chromatography, have indicated an association of aluminium with albumin $(8,9)$ and transferrin $(10-12)$. King and co-workers $(8,9)$, and Bertholf and co-workers (13) also reported the association of aluminium with low-molecular weight serum constituents. Furthermore, the ultrafiltrable low-molecular weight fraction is reported to increase with the total serum aluminium concentration $(9,14)$. The existence of a low-molecular weight aluminium species, however, has been challenged by others $(10-12)$.

The aim of this investigation was, therefore, to examine the speciation of aluminium in rat serum in relation to the total serum aluminium concentration, using a study for calcium speciation as a methodological model (15).

\section{Materials and Methods}

\section{Animals}

Female Wistar rats weighing between $200-230 \mathrm{~g}$ were fed a standard diet (Hope Farms, Linschoten, The Netherlands) with tap water ad libitum (aluminium concentration less than 10 $\mu \mathrm{g} / \mathrm{l})$. 
The animals were given 4 intraperitoneal injections of $1 \mathrm{ml}$ each, consisting of physiological saline containing different concentrations of aluminium $\left(\mathrm{AlCl}_{3} \times 6 \mathrm{H}_{2} \mathrm{O}\right)$, on day $1,3,4$, and 7 . The dosage scheme was thus chosen not to study a doseresponse relationship, but to achieve a range of serum concentrations. Therefore, two rats received a total dose of $0.8 \mathrm{mg}$ aluminium (1 mg per kg body weight every $48 \mathrm{~h}$ ), another 2 rats $4 \mathrm{mg}$ aluminium $(5 \mathrm{mg} / \mathrm{kg}$ body weight every $48 \mathrm{~h}$ ), and 2 rats $8 \mathrm{mg}$ aluminium $(10 \mathrm{mg} / \mathrm{kg}$ body weight weight every $48 \mathrm{~h})$. A control group of 4 rats received saline only. One rat receiving $5 \mathrm{mg} / \mathrm{kg}$ body weight died, so that the total number of animals for further investigation amounted to 9 .

On day 8 , the animals were killed by cardiac puncture under ether anaesthesia. Cardiac blood was collected with a 5-ml syringe and allowed to clot in an aluminium-free polypropylene tube $(13 \mathrm{ml}, 9.5 \times 1.6 \mathrm{~cm}$, Sarstedt No. 55.518, Nümbrecht, $\mathrm{W}$-Germany). After centrifugation at $4000 \mathrm{~g}$ for $15 \mathrm{~min}$, serum was separated and stored at $-20{ }^{\circ} \mathrm{C}$ to be analysed later.

\section{Gel filtration chromatography}

Gel filtration was performed on a Pharmacia C-series column, $1.6 \times 100 \mathrm{~cm}$ (Pharmacia Fine Chemicals No. 19-5104-01, Uppsala, Sweden). Sephacryl S-200 SuperFine (Pharmacia Fine Chemicals No. 17-0871-01, Uppsala, Sweden) was provided as a ready-to-use slurry. The column was packed with the slurry according to the manufacturer's manual.

The column eluent contained per litre: $140 \mathrm{mmol}$ sodium (130 mmol NaCl, $6.8 \mathrm{mmol} \mathrm{NaOH}$, and $3.0 \mathrm{mmol} \mathrm{NaN}_{3}$ ), $1.1 \mathrm{mmol}$ $\mathrm{CaCl}_{2}, 0.50 \mathrm{mmol} \mathrm{MgCl}_{2}, 4.0 \mathrm{mmol} \mathrm{KCl}$, and $10 \mathrm{mmol}$ tris(hydroxymethyl)-aminomethane (2-amino-2-hydroxymethyl1,3-propanediol, Fluka AG No. 93352, Buchs SG Switzerland) adjusted to $\mathrm{pH} 7.40 \pm 0.05$ at $4{ }^{\circ} \mathrm{C}$ with $1 \mathrm{~mol} / \mathrm{l} \mathrm{HCl}$. Both column and reservoir for the eluent were placed in a climate chamber $\left(4^{\circ} \mathrm{C}\right)$. The flow rate was maintained with a Perkin Elmer series 100 Pump (Perkin Elmer, Norwalk Conn., USA). The eluent fractions were collected into aluminium-free polypropylene tubes using an automated fraction collector (LKBProducter AB 2211 SuperRac, Bromma, Sweden).

Calibration of the column was performed with a Pharmacia calibration kit (Pharmacia Fine Chemicals No. 17-0442-01, Uppsala, Sweden). Using blue dextran 2000 , the void volume (Vo) was found to be $56 \mathrm{ml}$. Using ribonuclease A (relative molecular mass $=13700)$, chymotrypsinogen $\left(M_{\mathrm{r}}=25000\right)$, ovalbumin $\left(M_{\mathrm{r}}=43000\right)$, albumin $\left(M_{\mathrm{r}}=67000\right)$, and aldolase $\left(M_{\mathrm{r}}=158000\right)$ a calibration curve was determined and calculated:

$$
\mathrm{Kav}=-0.44 \log \left(M_{\mathrm{r}}\right)+2.4(\mathrm{r}=0.97) \text {. }
$$

One $\mathrm{ml}$ of serum was applied to the gel bed, and elution was started at a flow rate of $0.41 \mathrm{ml} / \mathrm{min}$. After elution of the void volume, collection of the fractions was started. Seventy fractions of $1.4 \mathrm{ml}$ each were collected per run in polypropylene tubes and stored at $4{ }^{\circ} \mathrm{C}$ to be analysed later.

\section{Atomic absorption spectrophotometry}

Aluminium in eluent and serum was analysed by electrothermal atomic absorption spectrophotometry (Perkin Elmer 2380 and HGA 500 graphite furnace, Perkin Elmer, Norwalk, Conn., USA). Pyrolytically coated graphite tubes (Perkin Elmer, No. 091504) were used. An aluminium hollow cathode lamp (Perkin Elmer) was operated at $25 \mathrm{~mA}$. Atomic absorption was measured at $309.3 \mathrm{~nm}$, with a spectral band width of $0.7 \mathrm{~nm}$.

The analysis of aluminium in serum has been described previously (16). For the determination of aluminium in the eluent the procedure was modified. Standard solutions containing 0 , $20,50,100,150$, and $200 \mu \mathrm{g} / \mathrm{l}$ aluminium were prepared in $2 \mathrm{~g} / 1$ Triton-X100 with $83.3 \mathrm{ml} / \mathrm{l}$ eluent. Samples were diluted 1:12 in $2 \mathrm{~g} / 1$ Triton-X100. A Perkin Elmer AS-40 model autosampler was used to inject $20 \mu \mathrm{l}$ volumes of standard solutions and samples. All aluminium analyses, both in serum and eluent, were performed in duplicate according to a previously described furnace program (16). The within-day precision of the aluminium assay in the eluent was established at $5.8 \%(100 \mu \mathrm{g} / \mathrm{l}$; $\mathrm{n}=10)$, the day-to-day precision at $6.8 \%(100 \mu \mathrm{g} / \mathrm{l} ; \mathrm{n}=6)$, and the detection limit at $2 \mu \mathrm{g} / \mathrm{l}$.

\section{Analysis of total protein, transferrin, and citrate}

Total protein was determined spectrophotometrically (Perkin Elmer 552 Norwalk, Conn., USA) with a standard Bio-Rad Microprotein Assay (17). Standards containing 0, 1, 2, 5, and $10 \mathrm{mg} / \mathrm{l}$ bovine serum albumin were used.

Transferrin in the eluent was analysed by Laurell "rocket" immunoelectrophoresis (18), using a LKB 2117 Multiphor (LKB-Producter AB, Bromma, Sweden). The agarose (LKBProducter AB No. 2206-101, Bromma, Sweden), containing $1.5 \%$ rabbit anti-transferrin serum, was prepared according to the manufacturer's manual. The electrophoresis was run with 20 volts per $\mathrm{cm}$ and at $10{ }^{\circ} \mathrm{C}$ for $6 \mathrm{~h}$. A series of 5 standards $(0.05,0.1,0.2,0.4$, and $0.5 \mathrm{~g}$ transferrin per $\mathrm{l})$ was applied to each plate. After electrophoresis the gel was placed in $0.2 \mathrm{~mol} / \mathrm{l}$ $\mathrm{NaCl}$ until the following day, when it was stained with amido black and dried.

Citrate was determined spectrophotometrically (Perkin Elmer 552, Perkin Elmer, Norwalk, Conn., USA) by a standard enzymatic technique (19). Standards containing $0,20,40,50,60$, 80 , and $100 \mu \mathrm{mol} / \mathrm{l} \mathrm{Na}$-citrate were used.

\section{Statistical procedures}

Pearson's correlation coefficients were calculated for the relation between the serum aluminium concentration and the aluminium/transferrin molar ratio, the serum aluminium concentration and the aluminium/citrate molar ratio, and the aluminium/transferrin molar ratio and the aluminium/citrate molar ratio. A partial correlation coefficient, correcting for serum aluminium concentration, was also calculated for the aluminium/transferrin molar ratio and the aluminium/citrate molar ratio (20).

One-sided $t$-tests were used to examine the hypotheses that true correlations were zero. Results with a $p<0.05$ were considered significant.

\section{Results}

\section{Elution pattern}

Gel filtration chromatography was performed with sera of 9 (4 non-treated and 5 aluminium-treated) rats containing low (less than $1 \mu \mathrm{mol} / \mathrm{l}$ ), intermediate (between 1 and $4 \mu \mathrm{mol} / \mathrm{l}$ ), and high (more than $4 \mu \mathrm{mol} / \mathrm{l}$ ) concentrations of aluminium. The elution pattern of all sera on the Sephacryl S 200 SF-Column showed two major aluminium peaks. The first aluminium peak co-eluted with protein in fractions 12 to $29\left(M_{\mathrm{r}}\right.$ between 112000 and 32000 ), with a maximum in fraction 20 . The second major aluminium peak eluted in fractions 53 to $68\left(M_{\mathrm{r}}<10000\right)$, with a maximum in fractions $58-62$. The presence of transferrin $\left(M_{\mathrm{r}}\right.$ $=81000$ ) (21) was demonstrated in fractions 12 to 26 , with a maximum in fractions $20-21$. In fractions 55 to 65 the presence of citrate was observed, with a maximum in fractions $59-60$ (fig. 1 and 2). 


\section{The Roots of Modern Biochemistry}

\section{Fritz Lipmann's Squiggle and its Consequences}

Editors Horst Kleinkauf, Hans von Döhren, Lothar Jaenicke

$1988.17 \mathrm{~cm}$ x $24 \mathrm{~cm}$. XII, 988 pages. Numerous illustrations.

Hardcover. DM 448,-; approx. US \$263.00 ISBN 3110115859

A Fritz Lipmann dedicatory volume, originating from the Memorial Meeting held in Berlin-Dahlem in 1987, presenting the major aspects of modern biochemistry and their development in 90 essays. The Warburg/Meyerhof era, the time of emigration and postwar science are revived. Contemporaries and coworkers together with other outstanding scientists describe the state of biochemistry in major fields: as it was, as it is now, and where it will be going. At the same time this volume is a reference book on Fritz Lipmann, the outstanding biochemist, and life scientist, who considered his concept of the energy-rich bond, symbolized by the squiggle, as his major achievement.

\section{From the Contents}

Fritz Lipmann 1899-1986 - Biochemistry Comes of Age ·

Molecular Biology Sharpens its Tools - Functional Dynamics:

The Squiggle-Symbol of Bioenergetics; Molecular Recognition and Communication · Evolution - List of Contributors · Lipmann's Coworkers at Massachusetts General Hospital, Boston, and the Rockefeller University, New York · Fritz Lipmann: Bibliography 1924-1985 · Author Index · Subject Index 


\section{Concise Encyclopedia Biochemistry}

\section{Second Edition,}

revised and expanded by Thomas Scott and Mary Eagleson

1988. $17 \mathrm{~cm} \mathrm{x} 24 \mathrm{~cm}$. 650 pages. Hardcover. DM 148,-; approx. US $\$ 89.00$

ISBN 3110116251

The only single work of its kind in English, the Concise Encyclopedia of Biochemistry provides a comprehensive, yet compact, source of biochemical data and information for the researcher, teacher, and student.

Following a five-year program of collecting and editing new material, as well as the revision of existing entries, the author-editors and the publishers are pleased to announce the new expanded Second Edition of this valuable reference work.

Major entries concerning the latest developments in DNA structure, synthesis, sequencing, binding proteins and methods, oncogenes, lymphokines and other newly discovered regulatory peptides, structural proteins, inositol phosphates, and protein kinases have been added. Graphic illustration has been given high priority, so that regulatory processes, transport, subcellular structures, etc. are abundantly and clearly illustrated.

The coverage of plant biochemistry has also been greatly expanded. Another new addition is a section on buffers which will be useful to anyone involved in laboratory work. Because of its comprehensiveness and multidisciplinary nature, we are sure that you will find it an indispensable reference tool.

Special features of this edition include:

- Approximately 4,500 entries

- Up-to-date, comprehensive

- Coverage of medical, animal, microbial, plant, and physical biochemistry, natural products, molecular biology, molecular genetics, and biotechnology

- Hundreds of illustrations, including structural formulas, schemes, and metabolic pathways

- Over 100 tables

- Modern terminology based on standard sources, e.g., IUB Enzyme Nomenclature

- Standard biochemical abbreviations

- Extensive cross references with synonyms provided

- Literature references are cited to aid the reader in locating original sources

Potential audience: biochemists, clinical biochemists, clinical chemists, medical researchers, clinicians, plant scientists, experimental biologists, lecturers and students of the life sciences. 

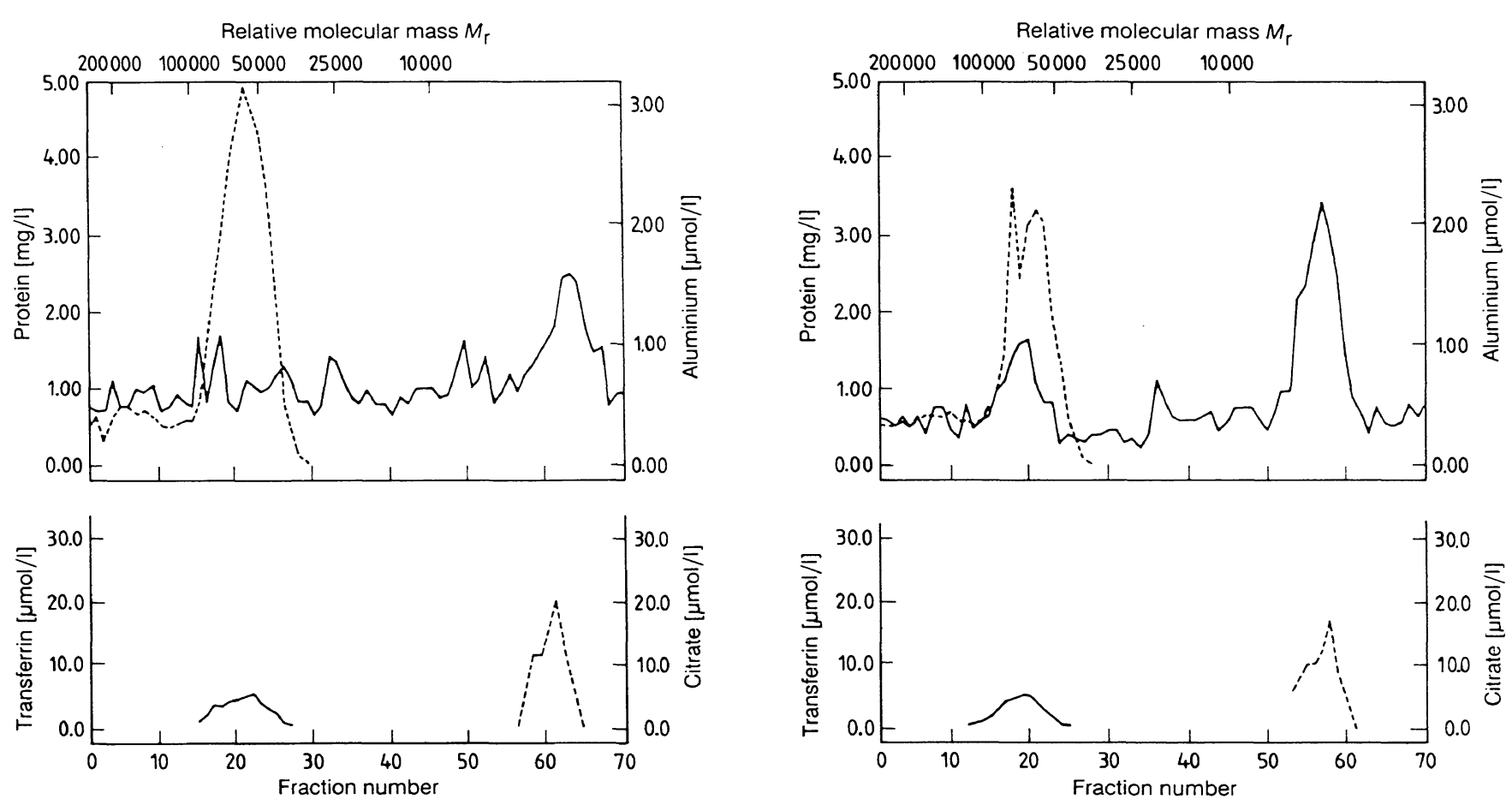

Fig. 1. Elution pattern of $1 \mathrm{ml}$ rat serum containing a low concentration of aluminium $(0.44 \mu \mathrm{mol} / \mathrm{l})$ on a Sephacryl S-200 SF column.

The solid line in the upper part of the figure represents the aluminium concentration (in $\mu \mathrm{mol} / \mathrm{l}$ ), whereas the dotted line represents the protein concentration (in $\mathrm{mg} / \mathrm{l}$ ) in the elution fractions. In the lower part, however, the solid line represents the transferrin concentration (in $\mu \mathrm{mol} / \mathrm{l}$ ), whereas the dotted line represents the citrate concentration (in $\mu \mathrm{mol} / \mathrm{l}$ ) in the fractions.

\section{Transferrin and citrate associated aluminium}

For those fractions where a simultaneous elution of aluminium and transferrin was detected, the molar ratio of aluminium to transferrin was calculated. An aluminium to citrate molar ratio was determined for those fractions where a co-elution of aluminium and citrate was observed (tab. 1).

Tab. 1. Relation between serum aluminium concentration and the aluminium/transferrin and aluminium/citrate molar ratio.

\begin{tabular}{lll}
\hline $\begin{array}{l}\text { Aluminium concen- } \\
\text { tration in serum } \\
(\mu \mathrm{mol} / \mathrm{l})\end{array}$ & $\begin{array}{l}\text { Aluminium/trans- } \\
\text { ferrin molar } \\
\text { ratio }\end{array}$ & $\begin{array}{l}\text { Aluminium/ } \\
\text { citrate molar } \\
\text { ratio }\end{array}$ \\
\hline 0.26 & 0.339 & 0.120 \\
0.44 & 0.326 & 0.081 \\
0.44 & 0.189 & 0.100 \\
0.82 & 0.347 & 0.110 \\
1.78 & 0.350 & 0.140 \\
2.67 & 0.334 & 0.141 \\
9.41 & 0.079 & 0.102 \\
9.48 & 0.223 & 0.096 \\
14.0 & 0.260 & 0.151 \\
\hline
\end{tabular}

A correlation coefficient of $\mathrm{r}=-0.54(p=0.03)$ was obtained for the relation between the serum aluminium concentration and the aluminium/transferrin molar ratio; the correlation coefficient for the serum aluminium concentration and the aluminium/citrate molar ratio was $\mathrm{r}=0.27(p=0.12)$.

A correlation coefficient of $0.33(p=0.10)$ was computed for the relation between the aluminium/transferrin molar ratio and the aluminium/citrate molar ratio. However, the partial correlation coefficient between aluminium/transferrin and the aluminium/citrate molar ratio was $\mathrm{r}=0.59(p=0.03)$.

\section{Discussion}

Gel filtration chromatography with rat sera was performed under equilibrium conditions with respect to temperature, osmolarity, and $\mathrm{pH}$. The sera, containing different concentrations of aluminium (ranging from 0.44 to $14.0 \mu \mathrm{mol} / 1$ ), were collected after the rats had been loaded intraperitoneally with aluminium. The elution profiles of sera showed two major alu- 
minimum peaks: one co-eluted with protein $\left(M_{\mathrm{r}}\right.$ between 112000 and 32000), while the other co-eluted with low-molecular weight serum constituents $\left(M_{\mathrm{r}}\right.$ $<10000$ ). The separating capacity of the column was restricted to compounds with a relative molecular mass between 200000 and 10000 . High-molecular mass proteins, such as macroglobulin, immunoglobulin $\mathrm{M}$, and orosomucoid were eluted in the void volume. As these proteins were not separated, their respective association with aluminium could not be studied in the present investigation.

The presence of transferrin was demonstrated in the protein peak co-eluting with aluminium. This is consistent with findings of others $(10-12)$, and supports the view that transferrin may act as a carrier for aluminium in plasma $(22,23)$. The negative correlation coefficient for the relation between the serum aluminium concentration and the aluminium/transferrin molar ratio $(\mathrm{r}=-0.54 ; p=0.03)$ suggests that the relative amount of aluminium bound to transferrin decreases when the serum aluminium concentration increases. Increased co-elution of free aluminium in the transferrin fractions from sera with a high aluminium concentration may explain this contradictory finding. The resolution of the column used in this study, however, was insufficiently high to exclude a possible aluminium-binding role for other proteins, especially albumin $\left(M_{\mathrm{r}}=67000\right)$.

The second aluminium peak co-eluted with low-molecular weight serum constituents $\left(M_{\mathrm{r}}<10000\right)$. Although ultrafiltration studies indicated that part of aluminium in serum is non-protein bound and ultrafiltrable $(12,14,24)$, co-elution of aluminium with low-molecular weight serum constituents has only been detected in some gel filtration studies $(8,9,13)$, while in other studies, using other types of gel, no association of aluminium with low-molecular weight species was found $(10-12)$.

Although citrate has often been nominated on theoretical or indirect grounds as a low-molecular weight binder for aluminium in plasma, association of aluminium with citrate has never been demonstrated before. The present finding strongly supports the postulated action of citrate as a chelator for aluminium in plasma $(23,25-27)$.

In addition, based upon recent reports on the effect of citrate on the intestinal absorption of aluminium (28), and on the accumulation of aluminium in bone and brain $(29,30)$, it is most likely that the passage of aluminium through the cell membrane is markedly increased when complexed to citrate. The aluminium/ citrate complex might therefore be of paramount importance for the intracellular accumulation of aluminium.

The ultrafiltrable aluminium fraction is reported to increase with the total serum aluminium concentration $(9,14)$. For the aluminium/citrate molar ratio, however, this could not be confirmed in the present study. This ratio appeared not to depend on the serum aluminium concentration $(\mathrm{r}=0.37 ; p=0.10)$.

Application of partial correlation calculations revealed that the aluminium/transferrin and the aluminium/citrate molar ratios are significantly correlated $(p=0.03)$. This observation suggests an association between transferrin and citrate in the binding of aluminium ions in plasma; and it supports the view that the behaviour of aluminium in plasma is very similar to that of iron (III), in which citrate acts as a chelator and the iron/citrate complex reacts with transferrin to form the transport complex (31).

Regarding the fraction of serum aluminium which coeluted with both transferrin and citrate, it was calculated that, on average, only $21 \%(\mathrm{SD}=2.5 \%)$; $\mathrm{n}=9$ ) of the total amount of aluminium recovered in 70 fractions was found in the transferrin peak, and that only $23 \%(\mathrm{SD}=8.2 \% ; \mathrm{n}=9)$ of the aluminium co-eluted with citrate. The recovery in the 70 fractions, however, was greater than the quantity of aluminium in the serum applied to the gel column. Contamination of the eluent with aluminium may be responsible for this. The aluminium/transferrin molar ratio was generally larger than the aluminium/citrate molar ratio (tab. 1), confirming that the affinity of aluminium for transferrin is greater than for citrate (23).

In conclusion, the observations of others that transferrin plays a role in the binding and transport of aluminium in serum was confirmed in this study. A comparable role for other proteins like albumin could, however, not be excluded.

In addition to transferrin, aluminium was shown to be associated with citrate in serum, resulting in a lowmolecular weight complex. In view of other studies in which citrate was shown to enhance aluminium transport in tissue, it may be assumed that the aluminium/ citrate complex in serum may play an important role in the intracellular accumulation, and hence toxicity, of aluminium.

\section{Acknowledgement}

The authors wish to thank Dr. A. H. Zwinderman (Department of Medical Statistics) for statistical advice. 


\section{References}

1. Flendrig, J. A., Kruis, H. \& Das, H. A. (1976) Aluminium and dialysis dementia. Lancet $I I, 1235$.

2. Alfrey, A. C., LeGendre, G. R. \& Kaehny, W. D. (1976) The dialysis encephalopathy syndrome. Possible aluminium intoxication. N. Engl. J. Med. 294, 184-188.

3. Wills, M. R. \& Savory, J. (1983) Aluminium poisoning: Dialysis encephalopathy, osteomalacia, and anaemia. Lancet II, 29-34

4. Crapper, D. R. Quittkat, S., Krishanan, S. S., Dalton, A. J. \& De Boni, U. (1980) Intranuclear aluminium content in Alzheimer's disease, dialysis encephalopathy, and experimental aluminium encephalopathy. Acta Neuropathol. 54, $19-24$.

5. Yoshimashu, F., Uebayashi, Y., Yase, Y., Iwata, S. \& Sasajima, K. (1976) Studies on amyotrophic lateral sclerosis by neutron activation analysis. Folia Psychiatr. Neurol. Japon. 30, 49-55.

6. Yoshimashu, F., Yasui, M., Yase, Y., Iwata, S., Gajdusek, D. G., Gibbs, C. J. \& Chen, K. M. (1980) Studies on amyotrophic lateral sclerosis by neutron analysis. 2. Comparative study of analytical results on Guam PD, Japanese ALS and Alzheimer disease cases. Folia Psychiatr. Neurol. Japon. 34, 75-82.

7. Ganrot, P. O. (1986) Metabolism \& possible health effects of aluminium. Environ. Health Perspect. 65, 363-441.

8. King, S. W., Wills, M. R. \& Savory, J. (1979) Serum binding of aluminium. Res. Comm. Chem. Pathol. Pharmacol. 26, $161-166$.

9. King, S. W., Savory, J. \& Wills, M. R. (1982) Aluminum distribution in serum following hemodialysis. Ann. Clin. Lab. Sci. 12, 143-149.

10. Trapp, G. A. (1983) Plasma aluminum is bound to transferrin. Life Sci. 33, 313-316.

11. Cochran, M. C., Patterson, D., Neoh, S., Stevens, B. \& Mazzachi, R. (1985) Binding of Al in plasma of patients on maintenance hemodialysis. Clin. Chem. 31, 1314-1316.

12. Rahman, H., Skillen, A. W., Channon, S. M., Ward, M. K. \& Kerr, D. N. S. (1985) Methods for studying the binding of aluminum by serum protein. Clin. Chem. 31, 1969-1973.

13. Bertholf, R. L., Wills, M. R. \& Savory, J. (1984) Quantitative study of aluminum binding to human serum albumin and transferrin by a chelex competitive binding assay. Biochem. Biophys. Res. Comm. 125, 1020-1024.

14. Elliott, H. L., MacDougall, A. I., Fell, G. S. \& Gardiner, P. H. E. (1978) Plasmaphereses, aluminium and dialysis dementia. Lancet $I I, 1255$.

15. Toffaletti, J., Savory, J. \& Gitelman, J. J. (1977) Use of gelfiltration to examine the distribution of calcium among serum proteins. Clin. Chem. 23, 2306-2310.

16. Van der Voet, G. B., De Haas, E. J. M. \& De Wolff, F. A. (1985) Monitoring of aluminium in whole blood, plasma, serum, and water by a single procedure using flameless atomic absorption spectrophotometry. J. Anal. Tox. 9, 97100.
17. Bradford, M. M. (1976) A rapid and sensitive method for the quantitation of microgram quantities of protein utilizing the principle of protein-dye binding. Anal. Biochem. $72,248-254$

18. Laurell, C. B. (1966) Quantitative estimation of proteins by electrophoresis in agarose gel containing antibodies. Anal. Biochem. 15, 45-52.

19. Tompkins, D. \& Toffaletti, J. (1982) Enzymatic determination of citrate in serum and urine, with use of the Worthington "Ultrafree" device. Clin. Chem. 28, 192-195.

20. Lindeman, R. H., Merenda, P. S. \& Good, R. Z. (1981) Introduction to bivariate and multivariate analysis, pp. $11-$ 117, Scott, Foresman, \& Company, London.

21. Van Eijk, H. G. \& Van Noort, W. L. (1976) Isolation of rat transferrin using $\mathrm{CNBr}$-activated Sepharose 4B. J. Clin. Chem. Clin. Biochem. 14, 475-478.

22. Trapp, G. A. (1986) Interactions of aluminum with cofactors, enzymes, and other proteins. Kidney Int. 29, S12S16.

23. Martin, B. R. (1986) The chemistry of aluminum as related to biology and medicine. Clin. Chem. 32, 1797-1806.

24. Lundin, A. P., Caruso, C., Sass, M. \& Berlyne, G. M. (1978) Ultrafiltrable aluminum in serum of normal man. Clin. Res. 26, 636A

25. Jackson, G. E. (1983) Studies on the chelation of aluminium for biological application. Part I. Citric acid. S. Afr. J. Chem. 35, Part III, 89-96.

26. Öhman, L. O. \& Sjöberg, S. (1983) Equilibrium and structural studies of silicone (IV) and aluminium (III) in aqueous solution. A potentiometric study of mono- and polynuclear aluminium (III) citrate. J. Chem. Soc. Dalton Trans. 3, 2513-2517.

27. Birchall, L. D. \& Chappell, J. S. (1988) The chemistry of aluminum and silicon in relation to Alzheimer's disease. Clin. Chem. 34, 265-267.

28. Van der Voet, G. B., Van Ginkel, M. F. \& De Wolff, F. A. (1989) Intestinal absorption of aluminum in rat: Energydependent and -independent processes. Tox. Appl. Pharm. 99, $90-97$

29. Slanina, P., Falkeborn, Y., Frech, W. \& Cedergren, A. (1984) Aluminium concentrations in the brain \& bone of rats fed citric acid, aluminium citrate or aluminium hydroxide. Fed. Chem. Toxic. 22, $391-397$.

30. Slanina, P., Frech, W., Bernhardson, A., Cedergren, A. \& Mattson, B. (1985) Influence of dietary factors on aluminium absorption and retention in the brain and bone of rat. Acta Pharmacol. Toxicol. 56, 331-336.

31. Bates, G. W., Billups, C. \& Saltman, P. (1967) The kinetics and mechanism of iron (III) exchange between chelates and transferrin. I. The complexes of citrate and nitriloacetic acid. J. Biol. Chem. 242, 2810-2815.

Prof. Dr. F. A. de Wolff

Toxicology Laboratory

P. O. Box 9600

NL-2300 RC Leiden 
